\title{
Interaction between the macrophyte Stratiotes aloides and filamentous algae: does it indicate allelopathy?
}

\author{
G. Mulderij · B. Mau • L. N. de Senerpont Domis • \\ A. J. P. Smolders · E. Van Donk
}

Received: 15 February 2008/ Accepted: 6 May 2008/Published online: 26 May 2008

(C) The Author(s) 2008

\begin{abstract}
The aquatic macrophyte Stratiotes aloides Linnaeus, which has recently received attention in studies on allelopathy, has been shown to suppress phytoplankton growth. In the Netherlands, S. aloides often co-occurs with floating filamentous algae. However, filamentous algae are generally absent in close proximity to $S$. aloides, resulting in gaps in filamentous algae mats. We analyzed whether those gaps may be caused by allelopathic substances excreted by $S$. aloides or by nutrient depletion. We studied in a field survey the colonization of natural S. aloides by filamentous algae and determined in situ nutrient concentrations in natural $S$. aloides stands. To analyze the relative importance of allelopathy and nutrient competition in the interaction between $S$. aloides and filamentous algae, we carried out field experiments. Introduction of artificial (non-allelopathic) plants in natural $S$. aloides stands enabled us to compare the
\end{abstract}

G. Mulderij · L. N. de Senerpont Domis .

E. Van Donk $(\bowtie)$

Department of Aquatic Food Webs, NIOO-KNAW Centre for Limnology, 3631 AC Nieuwersluis, The Netherlands

e-mail: e.vandonk@nioo.knaw.nl

G. Mulderij · A. J. P. Smolders · E. Van Donk Department of Ecology, Section Aquatic Ecology and Environmental Biology, Radboud University Nijmegen,

Toernooiveld 1, 6525 ED Nijmegen, The Netherlands

B. Mau

University of Konstanz, Limnological Institute, P.O. Box M659, 78457 Constance, Germany colonization by filamentous algae of both Stratiotes $\mathrm{sp}$. and artificial plants. The filamentous algae were absent in close vicinity to $S$. aloides. Significantly lower concentrations of ortho-phosphate and potassium were observed close to $S$. aloides as compared with the filamentous algae. In the field experiments the artificial plants were rapidly colonized by filamentous algae, mainly Cladophera Kützing and Spirogyra Link, while all natural plants remained free of such algae. Additionally, most nutrient concentrations did not significantly differ in the proximity of artificial or natural stands of $S$. aloides. The concentrations of the major growth-limiting nutrients, phosphate and nitrate, were significantly higher and nonlimiting in natural Stratiotes stands. Our main conclusion is that, although allelopathic interactions between $S$. aloides and filamentous algae do occur under natural conditions, nutrient competition between the two can also be an important factor.

Keywords Allelopathy · Filamentous algae ·

Macrophyte · Nutrient competition .

Nutrient limitation $\cdot$ Stratiotes aloides

\section{Introduction}

Research on the allelopathic interaction between aquatic plants and phytoplankton has shown that various plants possess allelopathic activity against phytoplankton 
(Gross et al. 2007). Examples of allelopathically active macrophytes are charophytes, Chara Linnaeus and Nitella Agardhi (Berger and Schagerl 2004); rigid hornwort, Ceratophyllum Linnaeus (Gross et al. 2003), and water milfoil, Myriophyllum Linnaeus (Gross and Sütfeld 1994; Hilt et al. 2006).

The allelopathic activity of the aquatic macrophyte water soldier (Stratiotes aloides Linnaeus) is less well studied. S. aloides plays a significant role in small aquatic ecosystems, being a rapid colonizer (Erixon 1979). An important part of the lifecycle of S. aloides is submerged (Bloemendaal and Roelofs 1988). The plants sink to the bottom of the lake and overwinter there as turions or entire (but rootless) plants. In spring, however, the plants become buoyant and remain floating on the water surface until autumn (De Geus-Kruyt and Segal 1973).

In a laboratory experiment with $S$. aloides, Jasser (1995) found inhibitory effects of $S$. aloides extracts on the growth of cyanobacteria (Anabaena Bory, Lyngbya Agardhii, and Oscillatoria Vaucher). Moreover, a field experiment with transparent plastic bags and extracts of $S$. aloides showed declining cyanobacterial densities in the presence of increasing concentrations of S. aloides extract. Brammer (1979), however, in a first study of Stratiotes-phytoplankton interactions, concluded that the decline of phytoplankton was likely to be due to competition for essential nutrients together with changes in the ionic composition of the water, rather than allelopathy. Furthermore, Brammer and Wetzel (1984) showed that, especially during its submerged phase, $S$. aloides can markedly lower the concentrations of potassium, sodium, and calcium in the water. These studies illustrate the ongoing debate on whether the observations of lower phytoplankton densities in the vicinity of macrophytes are caused by allelopathic interactions or by nutrient competition. The use of extracts (Jasser 1995) is no proof for allelopathic interactions between $S$. aloides and phytoplankton in situ (Willis 1985), and it provides no direct evidence that the plant actually releases allelopathic substances. Therefore, Mulderij et al. (2005a, b, 2007) used $S$. aloides exudates (instead of extracts) to test the plant's allelopathic activity on several phytoplankton species. Mulderij et al. (2005a) observed limitation of growth and colony formation of the green alga Scenedesmus obliquus (Turpin) Kützing when exposed to $S$. aloides exudates. In addition, the growth of the cyanobacterium Microcystis aeruginosa
Kützing and the eustigmatophyte Nannochloropsis limnetica Krienitz 1998/3 was significantly inhibited by $S$. aloides exudates (Mulderij et al. 2005b).

In addition to allelopathic interactions between S. aloides and phytoplankton, field observations of S. aloides stands also suggested allelopathic interactions between $S$. aloides and floating filamentous algae. During a survey of 18 Dutch S. aloides stands to study the allelopathic interaction between $S$. aloides and phytoplankton (Mulderij et al. 2006), we observed gaps in the mats of filamentous algae around the places where $S$. aloides plants emerged through the mats. In the Netherlands, S. aloides often occurs in stagnant, mesotrophic waters. Filamentous algae often co-occur with $S$. aloides and develop dense floatings mats. Such mats prevent sunlight from penetrating deeper into the water column, causing light limitation for all phototrophic organisms below these mats. Like $S$. aloides, filamentous algae also migrate in the water column. They start initially to develop at the lake/ditch bottom in spring, and then rise to the water surface (Scheffer 1998) where they can compete with S. aloides for nutrients.

We hypothesize that the aquatic macrophyte $S$. aloides may negatively influence the growth/ development of filamentous algae by the excretion of allelopathic substances or by nutrient depletion, resulting in gaps in the mats of filamentous algae. We conducted a field survey to assess the extent of colonization of $S$. aloides by filamentous algae and to determine in situ levels of nutrients in $S$. aloides stands with filamentous algae. As the filamentous algae cultures in our laboratory experiments were quickly replaced by phytoplankton species, we proceeded to focus on in situ experiments. Therefore, we executed two field experiments in which we introduced artificial plants in natural stands of $S$. aloides and compared the colonization by filamentous algae on both types of plants, i.e., natural versus artificial/ non-allelopathic plants.

\section{Materials and methods}

Field survey

A total of 18 natural Dutch S. aloides sites were sampled once: six sites in de Krimpenerwaard $\left(4^{\circ} 35^{\prime} \mathrm{E}\right.$, $\left.51^{\circ} 55^{\prime} \mathrm{N}\right)$, four sites in Tienhoven $\left(5^{\circ} 05^{\prime} \mathrm{E}, 52^{\circ} 10^{\prime} \mathrm{N}\right)$, 
three sites in Zegveld $\left(4^{\circ} 51^{\prime} \mathrm{E}, 52^{\circ} 07^{\prime} \mathrm{N}\right)$, and five sites in Giethoorn $\left(6^{\circ} 05^{\prime} \mathrm{E}, 52^{\circ} 45^{\prime} \mathrm{N}\right)$. In all of these sites $S$. aloides plants co-occurred with filamentous algae, predominantly consisting of species of the genera Spirogyra Link and Cladophora Kützing. These sites represented a range of trophic states, varying from oligotrophic to mesotrophic. We studied the presence of gaps in floating filamentous algae mats in close vicinity to $S$. aloides. In addition, we collected water samples in the middle of the S. aloides rosettes and in the filamentous algae mats occurring in close $(\sim 15 \mathrm{~cm})$ proximity to the $S$. aloides rosettes. The samples were pooled to a volume of $500 \mathrm{ml}$. We determined the nutrient concentrations (see Chemical analyses) of the $1.2 \mu \mathrm{m}$ (Whatman $\mathrm{GF} / \mathrm{C}$ filters) filtered water samples. Sampling was carried out between 16-25 July in 2002.

\section{Field experiments}

The purpose of our field experiment was to test for differences in the extent of colonization of filamentous algae on natural and artificial $S$. aloides plants.

We conducted the field experiments in a ditch close to Lake Naardermeer, the Netherlands $\left(5^{\circ} 06^{\prime} \mathrm{E}\right.$, $\left.52^{\circ} 19^{\prime} \mathrm{N}\right)$. In the spring of 2003 and 2004 we introduced 20 artificial, non-allelopathic plants, with a morphology similar to $S$. aloides, at two locations into the ditch (Loc 1 and Loc 2, at ca. $300 \mathrm{~m}$ distance from each other), resulting in a mixed stand of artificial and natural S. aloides plants later in the season. In 2004, the $S$. aloides plants at Loc 1 remained submerged and therefore we could not determine the development of filamentous algae in close vicinity to $S$. aloides at Loc 1 in 2004.

We took pooled water samples (filtered over $1.2 \mu \mathrm{m}$ Whatman GF/C, for nutrient analysis) every second week during the growing season at two sites per location: from both the rosettes of artificial plants and from an equal (as far as possible) amount of rosettes of natural $S$. aloides plants. The water samples were frozen immediately on arrival in the laboratory and stored for later analysis (see Chemical analyses). On each sampling occasion we also photographed the sites to determine the development of filamentous algae around natural and artificial plants.

Because we were also interested in the time of appearance of $S$. aloides and of filamentous algae on the water surface, we started the experiment before natural $S$. aloides plants or filamentous algae appeared on the water surface. In May-June the first natural plants started to appear on the water surface, but their numbers were not high ( $n=20$, Fig. 2). Due to the seasonal differences in the abundance of $S$. aloides, the sampling size of the natural plants was not constant during the study period. This disparity led to an unbalanced design, i.e., a fixed number of artificial plants but a variable number of natural plants.

The colonization on the plants was determined from photographs and categorized into three groups: $1=100 \%$ free of filamentous algae; $2=$ partly overgrown with filamentous algae; $3=100 \%$ overgrown with filamentous algae (algae were directly attached to the plants).

\section{Chemical analyses}

The $\mathrm{pH}$ of the samples taken during the field survey was determined in the laboratory using a combination glass electrode with an $\mathrm{Ag} / \mathrm{AgCl}$ internal reference (Orion Research, Beverly, USA). The alkalinity of the survey samples was determined by titrating $50 \mathrm{ml}$ of the water sample down to $\mathrm{pH} 4.2$ with $0.01 \mathrm{M}$ $\mathrm{HCl}$.

All following analyses were conducted for samples of both the field survey and the field experiments. Nitrate and ammonium were measured colorimetrically with a Traacs $800+$ auto-analyzer, using hydrazine sulfate (Technicon 1969) and salicate (Grasshoff and Johannsen 1977) as reductive agents, respectively. Ortho-phosphate was determined colorimetrically with a Technicon II auto-analyzer (Henriksen 1965). Furthermore several other chemicals were analyzed because Brammer and Wetzel (1984) showed that, especially during its submerged phase, $S$. aloides can markedly lower the concentrations of potassium, sodium, and calcium in the water. Potassium and sodium were measured by flame photometry (FLM3 Flame Photometer, Radiometer, Copenhagen, Denmark). Aluminum, calcium, iron, magnesium, manganese, phosphorus, silicon, sulfur, and zinc were determined by inductively coupled plasma emission spectrophotometry (Spectro Analytical Instruments, type Spectroflame, Kleve, Germany).

\section{Statistical analyses}

The data on $\mathrm{pH}$, alkalinity, and nutrient concentrations were tested for normality and homogeneity of 
variances. The ammonium data for the field experiment in 2003 were not normally distributed and therefore log-transformed. The (transformed) data were analyzed by means of paired samples $T$-tests $(\alpha=0.05$, Fowler et al. 1998; Sokal and Rohlf 1995).

We analyzed the categorical data of the filamentous algae colonisation with chi-square tests $(\alpha=0.05)$. Despite this rather crude assessment of cover (with only three categories), we found highly significant results (see Results, Field experiments) and therefore we decided not to refine the method by increasing the number of categories. The colonization by filamentous algae on each location was classified by plant type (artificial, natural), sampling date (see Materials and methods, Field experiments), and sampling year $(2003,2004)$. The null hypothesis was that colonization of filamentous algae on each location is independent of plant type, sampling date, and sampling year. The $\chi^{2}$ statistic $(\alpha=0.05)$ was used to test the null hypothesis. All statistical analyses were performed in SPSS version 11.5 (Dytham 1999).

\section{Results}

Field survey

Our study of $18 \mathrm{~S}$. aloides stands showed that between $85 \%$ and $100 \%$ of the S. aloides plants were not colonized by filamentous algae and algae-free gaps of at least $5 \mathrm{~cm}$ around the natural $S$. aloides plants occurred. The $\mathrm{pH}$ and alkalinity (alk) of water samples taken in the vicinity of $S$. aloides and samples taken close to filamentous algae did not differ significantly $\left(t_{\mathrm{alk}}=0.59, \mathrm{df}_{\mathrm{alk}}=14, P_{\mathrm{alk}}=\right.$ 0.56 and $t_{\mathrm{pH}}=1.39, \mathrm{df}_{\mathrm{pH}}=17, P_{\mathrm{pH}}=0.18$ ). Nutrient concentrations in the rosettes of $S$. aloides were often significantly correlated with the concentration found in the vicinity of filamentous algae (Pearson's product-moment correlation $0.51-1.00$ for the different nutrients). The paired samples $T$-tests, however, only showed significant differences in the mean concentration of ortho-phosphate, potassium, and silicate between water samples taken in the vicinity of $S$. aloides and those taken close to the filamentous algae. The silicate concentration was significantly higher $(t=-4.38$, df $=17, \quad P<0.001)$ in the rosettes of $S$. aloides than in the filamentous algae, but the opposite was true for ortho-phosphate $(t=2.43, \quad \mathrm{df}=17, \quad P=0.03) \quad$ and potassium ( $t=4.04$, df $=17, P<0.001)$. For the latter two potentially significantly lower concentrations of growth-limiting nutrients were found close to $S$. aloides (Fig. 1a, b). The concentration of potentially other growth-limiting nutrients, such as nitrate and ammonium, did not significantly differ in stands with S. aloides or close to the filamentous algae (Fig. 1c). The water around the plants was not mixed because the sites were sheltered against wind and waves.

Field experiments

During the experiments most artificial plants soon became heavily overgrown with filamentous algae (they were directly attached to the plants), mainly consisting of Spirogyra Link and Cladophora Kützing species (Fig. 2), while nearly all natural $S$. aloides plants remained free of these filamentous algae during the entire experiment (Fig. 2) in both years. Chi-square tests showed that, at each location, natural $S$. aloides plants were significantly less overgrown with filamentous algae than artificial plants (Pearson $\chi^{2}$ Loc 1: 78.4, $P<0.001$; Pearson $\chi^{2}$ Loc 2: $\left.170.9, P<0.001\right)$. On Loc 2 the observations did not differ between years (Pearson $\chi^{2}$ Loc 2 : $2.533, P=0.279)$. Effects of subsequent years could not be tested for Loc 1 because we only conducted an experiment at this location in 2003 (see Materials and methods). Furthermore, on each location the observations differed significantly over the season (Pearson $\chi^{2}$ Loc 1: 55.0, $P<0.001$; Pearson $\chi^{2}$ Loc 2: $110.9, P<0.001)$ as the plants became more heavily overgrown with filamentous algae towards the end of the season. Neither artificial nor natural $S$. aloides plants were heavily overgrown by periphyton.

In 2003 the water samples from the proximity of natural or artificial $S$. aloides plants at Loc 1 did not differ in nutrient concentrations. At Loc 2 only the concentration of ortho-phosphate and total phosphorus significantly differed (Fig. 3). Concentrations of both ortho-phosphate $(F=12.41, \mathrm{df}=2, P=0.019)$ and total phosphorus $(F=8.12$, df $=2, P=0.039)$ in the vicinity of $S$. aloides were significantly higher than those close to the artificial plants (Fig. 3). In 2004 only the nitrate concentrations were significantly higher ( $F=5.99, \mathrm{df}=2, P=0.037)$ close to $S$. aloides at 

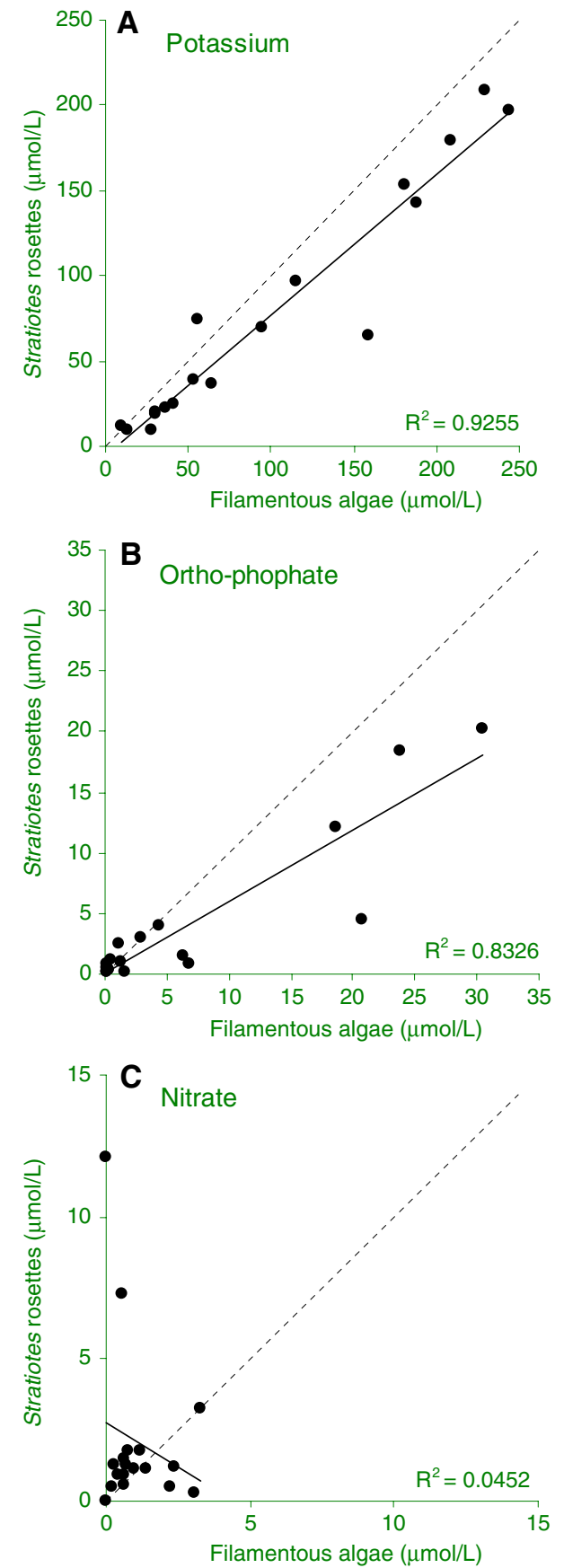

Fig. 1 Relationship between nutrient concentrations of field survey samples taken in rosettes of $S$. aloides and close to the filamentous algae (solid line): (a) potassium, (b) ortho-phosphate, and (c) nitrate. Dashed line indicates equal concentrations of nutrients sampled in the rosettes of $S$. aloides and close to the filamentous algae

Loc 1 (Fig. 4). For the nutrients other than nitrate and for all nutrient concentrations estimated for Loc 2 no significant differences were found $(P>0.05)$.

\section{Discussion}

With respect to the ongoing debate on the importance of nutrient competition versus that of allelopathic interactions, we demonstrate the existence of some allelopathic interactions between $S$. aloides and filamentous algae. We also show highly significant differences between the colonization of natural and artificial $S$. aloides plants by filamentous algae. These observations cannot be explained exclusively by nutrient limitation of filamentous algae, as the nutrient concentrations in the vicinity of natural, algae-free $S$. aloides plants were never lower than concentrations in the vicinity of artificial plants overgrown with filamentous algae.

Most nutrients close to $S$. aloides and close to filamentous algae do not significantly differ in their concentrations. Furthermore, these concentrations are well above levels that limit algal growth. Both orthophosphate and potassium values in the vicinity of S. aloides did differ significantly, suggesting that their limitation may contribute to low densities of filamentous algae close to $S$. aloides plants. These observations correspond with those of Brammer (1979) and Brammer and Wetzel (1984). These authors consider competition for essential nutrients together with changes in the ionic composition of the water as the most likely explanation for lower phytoplankton densities close to $S$. aloides plants. Both our study and those of Brammer (1979) and Brammer and Wetzel (1984), however, do not completely exclude a possible role of allelopathy, but merely indicate that the availability of nutrients may be influenced by $S$. aloides via uptake and thus may also play a role. Allelopathy and nutrient limitation may act as multiple stressors in causing algae-free gaps around natural $S$. aloides plants.

Alternatively, the gaps in filamentous algae could have been caused by mechanical interference of $S$. aloides. Gaps could be created when S. aloides plants slightly move around. However, the artificial (nonallelopathic) plants with a morphology (and way of moving by wind/waves) similar to natural $S$. aloides plants became completely overgrown with filamentous algae. So the mechanical interference hypothesis is not very plausible.

Additionally, light limitation due to shading by macrophytes may play a role in the interaction between primary producers like a macrophyte and phytoplankton 

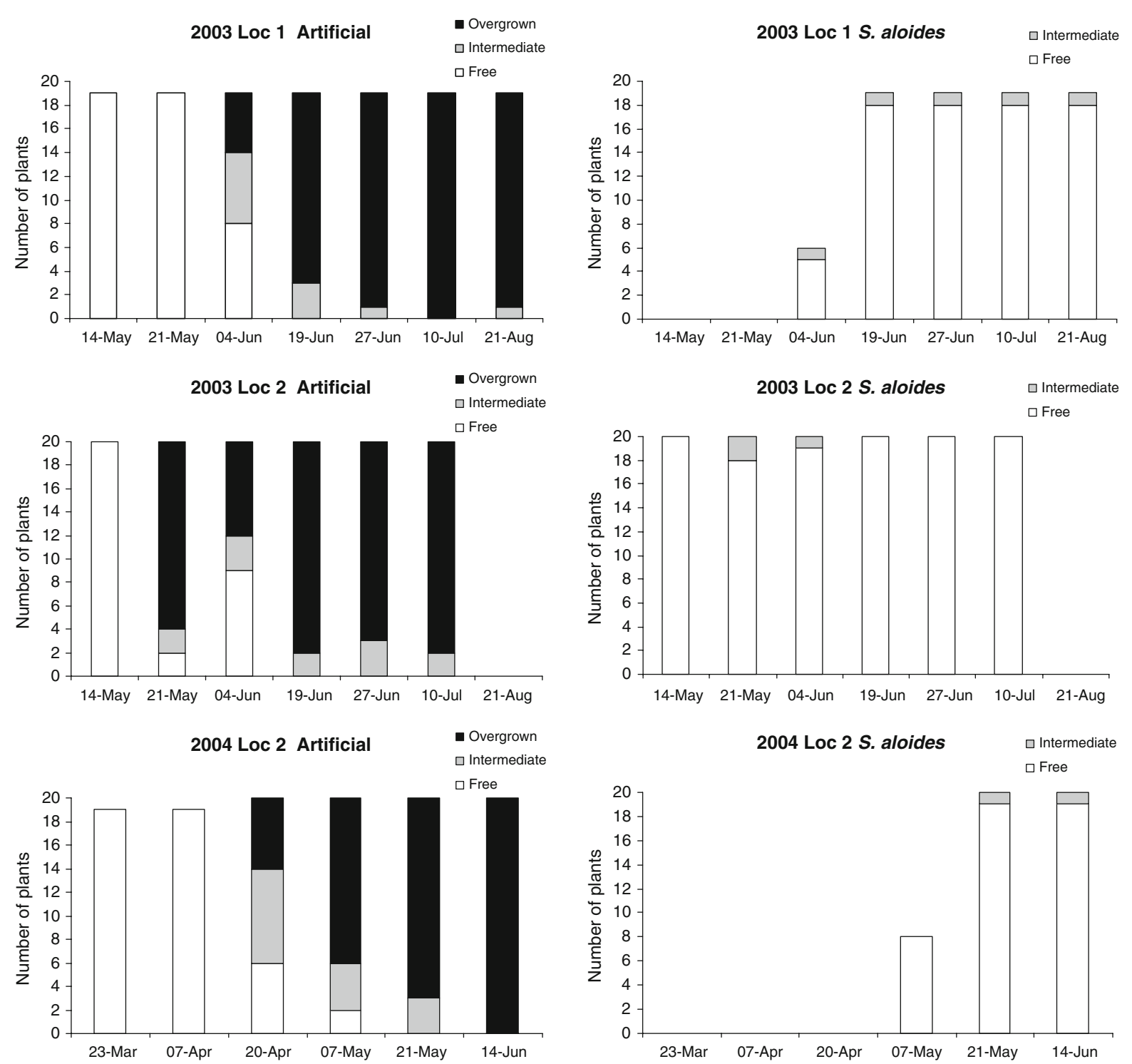

Fig. 2 Colonization of artificial (left) and natural (right) $S$. aloides plants with filamentous algae during the experiments in 2003 (upper four graphs) and 2004 (lower two graphs) at Loc 1 and Loc 2 (see graph titles). Plants were classified in three

(Sand-Jensen 1989; Ozimek et al. 1990), but we assume that shading plays a less important or no role in the interaction between $S$. aloides and filamentous algae as both species occur on the water surface in direct sunlight. Moreover, filamentous algae appeared on the water surface before $S$. aloides, indicating that, during the early movement of filamentous algae from the sediment towards the water surface in spring, it is unlikely that these algae experienced light limitation as a consequence of the presence of $S$. aloides.

categories. Plants were either $100 \%$ free of filamentous algae $(=$ Free $)$ or $100 \%$ overgrown with filamentous algae (=Overgrown) or partly covered with filamentous algae (=Intermediate)

The use of artificial S. aloides plants in our field experiments enabled us to mimic the presence of $S$. aloides as a structural/physical component of the aquatic food web. Higher densities of zooplankton (Jeppesen et al. 1998; Irvine et al. 1990) and macrofauna (Higler 1977; Kornijow et al. 1990) seem to be related to the presence of macrophytes which function as refuges or habitats. Higler (1977) conducted experiments with artificial $S$. aloides plants and showed that, in comparison to living plants, artificial 


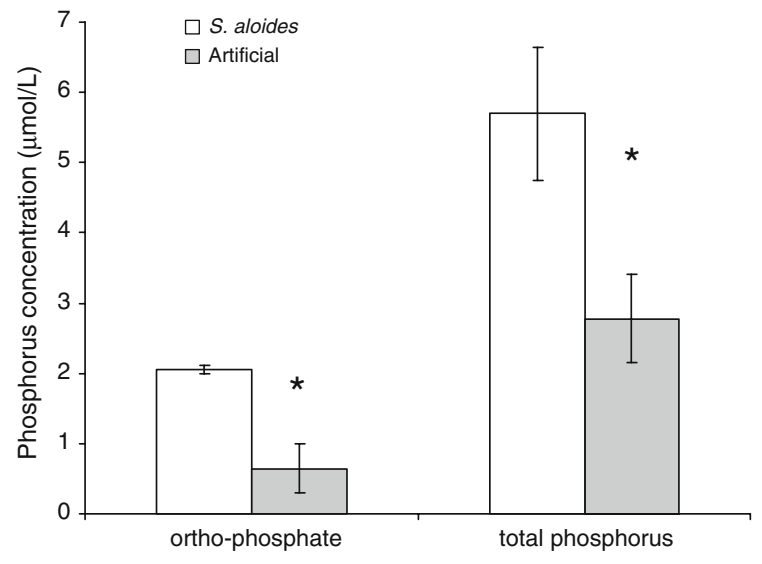

Fig. 3 Concentrations of ortho-phosphate and total phosphorus found in water in the vicinity of natural $S$. aloides and close to the artificial plants. Bars represent average values $(n=7)$ with associated error bars $( \pm 1 \mathrm{SE})$. *indicates the significant difference between the treatments (artificial and natural $S$. aloides plants)

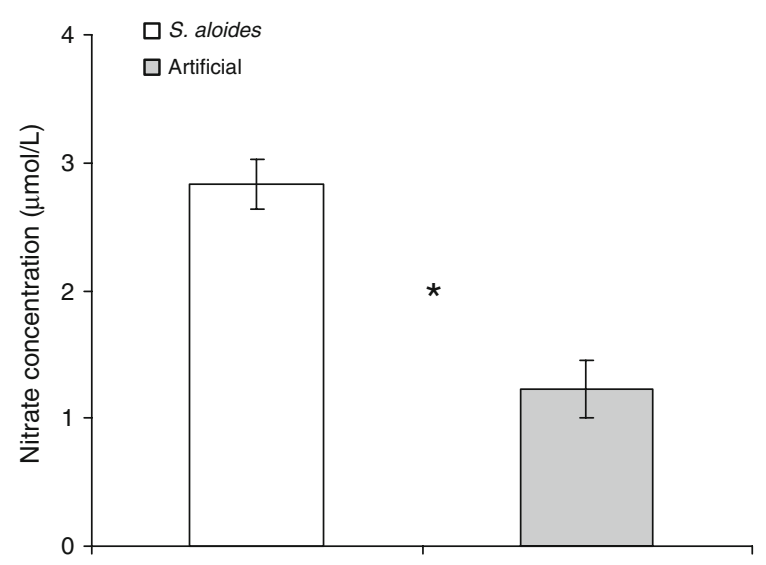

Fig. 4 Concentrations of nitrate in water taken in the vicinity of $S$. aloides and close to the artificial plants. Bars represent average values $(n=7)$ with associated error bars $( \pm 1 \mathrm{SE})$. *indicates the significant difference between the treatments (artificial and natural S. aloides plants)

plants could accommodate comparable numbers and about $90 \%$ of the same species of macroinvertebrates. Based on this study we therefore assume that it is unlikely that grazing of filamentous algae by macrofauna explains the absence of these algae in the vicinity of $S$. aloides.

Our study is a first step in establishing the nature of the interaction between $S$. aloides and filamentous algae. The results of our study indicate that allelopathic interactions between $S$. aloides and filamentous algae may occur under natural conditions, but does not completely exclude competition for nutrients as an important factor.

Acknowledgments Parts of this research were financed by the Schure-Beijerinck Popping fund (SBP-2001-29). We are also grateful to Natuurmonumenten for their permission to conduct experiments in a ditch close to Lake Naardermeer.

Open Access This article is distributed under the terms of the Creative Commons Attribution Noncommercial License which permits any noncommercial use, distribution, and reproduction in any medium, provided the original author(s) and source are credited.

\section{References}

Berger J, Schagerl M (2004) Allelopathic activity of Characeae. Biologia 59:9-15

Bloemendaal FHJL, Roelofs JGM (1988) Waterplanten en waterkwaliteit. Stichting Uitgeverij KNNV, Utrecht, The Netherlands, p 189

Brammer ES (1979) Exclusion of phytoplankton in the proximity of dominant water soldier (Stratiotes aloides). Freshw Biol 9:233-249. doi:10.1111/j.1365-2427.1979. tb01506.x

Brammer ES, Wetzel RG (1984) Uptake and release of $\mathrm{K}^{+}, \mathrm{Na}^{+}$ and $\mathrm{Ca}^{2+}$ by the water soldier, Stratiotes aloides L. Aquat Bot 19:119-130. doi:10.1016/0304-3770(84) 90012-3

De Geus-Kruyt M, Segal S (1973) Notes on the productivity of Stratiotes aloides in two lakes in the Netherlands. Pol Arch Hydrobiol 20:195-205

Dytham C (1999) Choosing and using statistics a biologist's guide. Blackwell Science, Oxford, UK, p 218

Erixon G (1979) Population ecology of a Stratiotes aloides L. stand in a riverside lagoon in N. Sweden. Hydrobiologia 67:215-221. doi:10.1007/BF00023178

Fowler J, Cohen L, Jarvis P (1998) Practical statistics for field biology. Wiley, Chichester UK, p 259

Grasshoff K, Johannsen H (1977) A new sensitive method for the determination of ammonia in sea water. Water Res 2:516

Gross EM, Sütfeld R (1994) Polyphenols with algicidal activity in the submerged macrophyte Myriophyllum spicatum $\mathrm{L}$. Acta Hortic 381:710-716

Gross EM, Erhard D, Ivanyi E (2003) Allelopathic activity of Ceratophyllum demersum L. and Najas marian ssp. intermedia (Wolfgang) Casper. Hydrobiologia 506/509: 583-589. doi:10.1023/B:HYDR.0000008539.32622.91

Gross EM, Hilt S, Lombardo P, Mulderij G (2007) Searching for allelopathic effects of submerged macrophytes on phytoplankton — state of the art and open questions. Hydrobiologia 584:77-88. doi:10.1007/s10750-007-0591-z

Henriksen A (1965) An automated method for determining lowlevel concentratrions of phosphate in fresh and saline waters. Analyst (Lond) 90:29-34. doi:10.1039/an9659000029 
Higler LWG (1977) Macrofauna-cenoses on Stratiotes plants in Dutch broads. PhD-thesis University of Amsterdam, The Netherlands

Hilt S, Ghobrial MGN, Gross EM (2006) In situ allelopathic potential of Myriophyllum verticillatum (Haloragaceae) against selected phytoplankton species. J Phycol 42:11891198. doi:10.1111/j.1529-8817.2006.00286.x

Irvine K, Moss B, Stansfield J (1990) The potential of artificial refugia for maintaining a community of large-bodied Cladocera against fish predation in a shallow eutrophic lake. Hydrobiologia 200-201:379-390. doi:10.1007/BF02530355

Jasser I (1995) The influence of macrophytes on a phytoplankton community in experimental conditions. Hydrobiologia 306:21-32. doi:10.1007/BF00007855

Jeppesen E, Søndergaard M, Søndergaad M, Christoffersen K (1998) The structuring role of submerged macrophytes in lakes. Ecological Studies 131. Springer-Verlag, New York, p 423

Kornijow R, Gulati RD, Van Donk E (1990) Hydrophyte macroinvertebrate interactions in Zwemlust, a lake undergoing biomanipulation. Hydrobiologia 200/201:467-474. doi:10.1007/BF02530364

Mulderij G, Mooij WM, Van Donk E (2005a) Allelopathic growth inhibition and colony formation of the green alga Scenedesmus obliquus by the aquatic macrophytes Stratiotes aloides. Aquat Ecol 39:11-21. doi:10.1007/s10452-0041021-1

Mulderij G, Mooij WM, Smolders AJP, Van Donk E (2005b) Allelopathic inhibition of phytoplankton by exudates from
Stratiotes aloides. Aquat Bot 82:84-296. doi:10.1016/ j.aquabot.2005.04.001

Mulderij G, Smolders AJP, Van Donk E (2006) Allelopathic effect of the aquatic macrophyte, Stratiotes aloides, on natural phytoplankton. Freshw Biol 51:554-561. doi: 10.1111/j.1365-2427.2006.01510.x

Mulderij G, Mau B, Van Donk E, Gross EM (2007) Allelopathic activity of stratiotes aloides on phytoplanktontowards identification of allelopathic substances. Hydrobiologia 584:89-100. doi:10.1007/s10750-007-0602-0

Ozimek T, Van Donk E, Gulati RD (1990) Can macrophytes be useful in the biomanipulation of lakes? The Lake Zwemlust example. Hydrobiologia 200/201:399-409. doi: 10.1007/BF02530357

Sand-Jensen K (1989) Environmental variables and their effect on photosynthesis of aquatic plant communities. Aquat Bot 32:5-25. doi:10.1016/0304-3770(89) 90048-X

Scheffer M (1998) Ecology of shallow lakes. Chapman \& Hall, London UK, p 356

Sokal RR, Rohlf FJ (1995) Biometry. W. H. Freeman, New York, USA, p 887

Technicon (1969) Industrial method 33-69 W, nitrate + nitrite in water. Technicon autoanalyser methodology. Technicon Corporation, Karrytown, New York

Willis RJ (1985) The historical bases of the concept of allelopathy. J Hist Biol 18:71-102. doi:10.1007/BF00127958 